WARSZTATY Z GEOGRAFII TURYZMU

ISBN 978-83-7525-713-7 s. 135-147

http://dx.doi.org/10.18778/7525-713-7.09

Witold PÓŁTORAK, Grzegorz BIELEC

Uniwersytet Rzeszowski

\title{
ZNACZENIE TRAGICZNYCH WYDARZEŃ HISTORYCZNYCH DLA TURYSTYKI NA PRZYKŁADZIE RODZINY ULMÓW W MARKOWEJ
}

\begin{abstract}
Wstęp
Druga wojna światowa była bez wątpienia jednym z najtragiczniejszych wydarzeń w historii ludzkości. Pochłonęła wiele milionów ofiar, wśród których większość stanowiła ludność cywilna. Działania wojenne szczególnie tragicznie dotknęły ludność polska, w tym mieszkańców Podkarpacia. Wydarzenia z 24 marca 1944 r., które miały miejsce we wsi Markowa (powiat łańcucki) są odzwierciedleniem bestialskiej istoty kary śmierci za ukrywanie ludności żydowskiej. Po latach badań i próbach dokumentacji zjawiska ukrywania Żydów w domach miejscowej ludności zdołano zebrać wiele istotnych informacji. Wielu Żydom dzięki ofiarności i heroicznej postawie markowian udało się przeżyć. Kwestie te zaczęto dość powszechnie omawiać w środkach społecznego przekazu, co przyczyniło się do wzrostu zainteresowania tymi wydarzeniami zarówno w Polsce, jak i na świecie.

Niniejsza praca przedstawia relacje pomiędzy tragicznym wydarzeniem, jakim było bestialskie zamordowanie rodziny Ulmów a powstaniem ogólnego zainteresowania tą kwestią i jej roli w rozwoju ruchu turystycznego
\end{abstract}


w obecnych czasach. Od kiedy wiedza na temat życia i czynów Józefa i Wiktorii Ulmów rozpowszechniła się w kraju i zagranica, wieś stała się obiektem zainteresowań ze strony rozlicznych środowisk, instytucji i organizacji. Niebywale największym aspektem rozwoju turystyki w Markowej są pielgrzymki Żydów, którzy zbierają się licznie wokół pomnika, oddając hołd pomordowanym rodzinom. Markowa stała się dla nich kolejną ważną miejscowością na ich szlaku pielgrzymkowym po Leżajsku i Łańcucie (POTOCKI 2004, s. 92 105). Stopniowo rośnie również liczba Polaków zainteresowanych losami i bohaterską postawą rodziny Ulmów. Pozyskując informacje na temat rodziny ze środków społecznego przekazu decydują się odwiedzić miejsce, w którym żyli Ulmowie - co dodatkowo przyczynia się do rozwoju turystyki poznawczej na tym terenie.

Zasadniczym celem niniejszej pracy jest wykazanie znaczenia tragicznych wydarzeń historycznych dla ruchu turystycznego w Markowej i sąsiednich miejscowościach. Migracje turystyczne mogą bowiem powstawać $z$ różnych przyczyn, np. z chęci zaspokojenia ciekawości, poznania historii, sentymentu, oddania czci, pielgrzymki Żydów okazujących swą wdzięczność ${ }^{1}$ itp. $\mathrm{W}$ ostatnich latach wydarzenia związane $\mathrm{z}$ rodziną Ulmów silnie wpływają na wizerunek wsi. Jednak podejmowane działania, takie jak: rozpoczęcie procesu beatyfikacyjnego, budowa pomnika, organizowanie wystaw i spotkań istotnie zmieniają liczbę osób odwiedzających wieś i jej okolice. Fakt ten przyczynił się do powstania projektu wybudowania na terenie wsi Muzeum Polaków Ratujących Żydów na Podkarpaciu im. Rodziny Ulmów, co w konsekwencji może spowodować dynamiczny rozwój wsi zarówno pod względem społecznym, ekonomicznym, jak i turystycznym.

\section{Ofiara rodziny Ulmów w Markowej}

Józef Ulma urodził się w 1900 r. w Markowej, w ubogiej rodzinie rolniczej. Ukończył czteroklasową szkołę powszechną. W roku 1921 powołany został do służby wojskowej. W latach 1927-1928 uczęszczał do szkoły rolniczej w Pilźnie. W swoim późniejszym życiu, wykorzystał zdobyte tam doświadczenie i wiedzę $\mathrm{w}$ dziedzinie ogrodnictwa oraz sadownictwa (WAWSZCZAK 1993, s. 461). Jego największą pasją było jednak fotografowanie. Fotografie,

\footnotetext{
1 Jak podaje PTASZYCKA-JACKOWSKA (2007, s. 292-295): „,Turystyką religijną (pielgrzymkową) są podróże podjęte $\mathrm{z}$ motywów religijnych lub religijno-poznawczych i tym samym stanowią specyficzny typ podróży turystycznych. Celem turystyki religijnej jest dotarcie do świętego miejsca (ośrodku kultu, sanktuarium)...".
} 
które wykonał zachowały się w wielu domach po dzień dzisiejszy. Utrwalał nie tylko życie najbliższych, ale miejscowe uroczystości, występy chóru, orkiestry, dożynki, przedstawienia teatralne, wesela, pierwsze komunie święte. Robił także zdjęcia na zamówienie i portrety do dokumentów. Dzięki temu był sławny na całą okolicę (SZPYTMA, SZAREK 2007, s. 18).

$\mathrm{W}$ połowie lat 30. XX w. Józef spotkał swoją przyszłą żonę Wiktorię. Mieszkała kilka domów dalej, jednak poznali się dopiero na zebraniu miejscowego koła Związku Młodzieży Wiejskiej „Wici”. Pobrali się w 1935 r. i szybko doczekali się potomstwa (fot. 1 i 2). Jako pierwsza, latem 1935 r., przyszła na świat Stasia. Jeszcze przed wojną urodzili się Basia i Władziu. W ciągu następnych lat rodzina powiększyła się o kolejne dzieci: Franusia, Antosia i Marysię. W 1944 r. na świat miało przyjść siódme dziecko.

Wiktoria, będąc uczestniczką zajęć w Wiejskim Uniwersytecie Ludowym im. W. Orkana w Gaci, miała wykształcenie, które wykorzystywała w codziennym życiu (por. PÓŁTORAK 2006, s. 40-55). Była dobrą matka, która nie tylko opiekowała się rodzina, ale pomagała dzieciom w nauce pisania, rysowania itd.

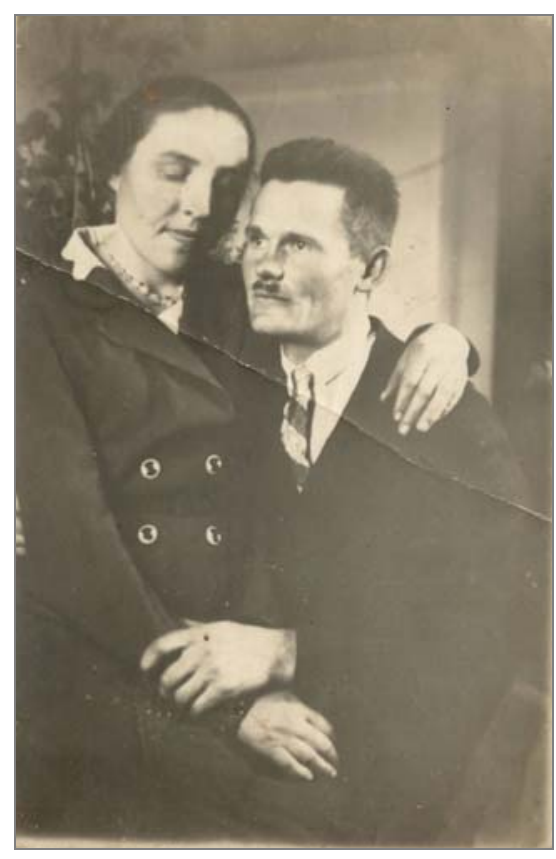

Fot. 1. Józef i Wiktoria Ulmowie (1936 r.) (ze zbiorów Jerzego Ulmy) 


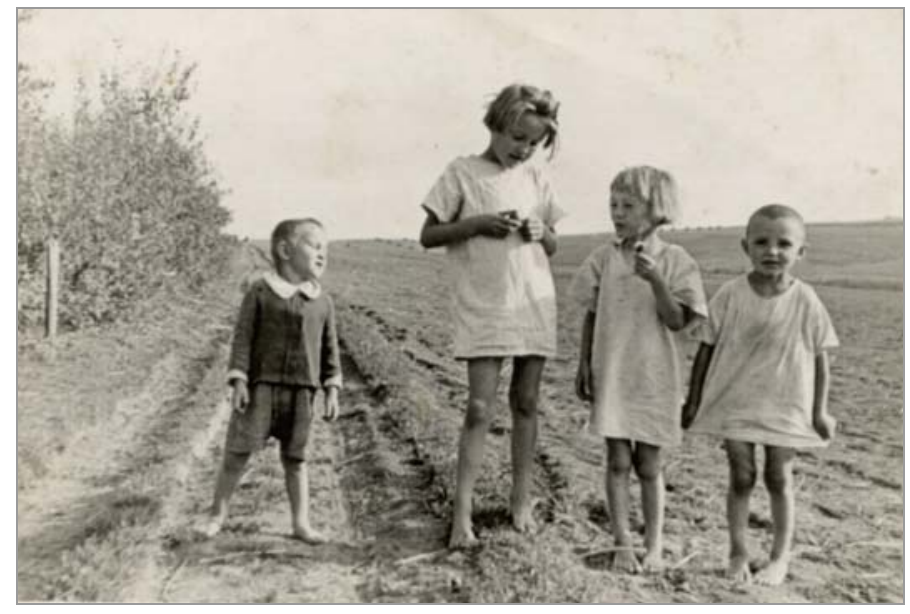

Fot. 2. Dzieci Ulmów: Franuś, Stasia, Basia, Władziu (ok. 1942 r.) (ze zbiorów Jerzego Ulmy)

W roku 1937 Józef z wypracowanych środków kupił kilkanaście hektarów ziemi oraz drewniany dom $\mathrm{w}$ sąsiedztwie. Cała rodzina cieszyła się z perspektywy poprawy warunków życia i podjęła starania przygotowujące do przeprowadzki. Wybuch II wojny światowej uniemożliwił im jednak opuszczenie Markowej.

Wraz z wkroczeniem wojsk niemieckich na ziemie Polski życie mieszkańców Markowej zaczęło się znacznie komplikować. W roku 1939 ukazał się dekret, na mocy którego polskie ziemie zachodnie i północne zostały włączone do Rzeszy, zaś pozostałe potraktowano jako „okupowane polskie obszary” - połączone w tzw. Generalną Gubernię (DOBOSZ 1993, s. 93). W wyniku nowego podziału administracyjnego gmina Markowa mieściła się w powiecie jarosławskim w dystrykcie krakowskim. Do utrzymania porząd$\mathrm{ku}$ na terenach wiejskich i w mniejszych miastach powołano żandarmerię wchodzącą w skład Policji Porządkowej. Życie podczas okupacji hitlerowskiej drastycznie się zmieniło, gdyż terror, godzina policyjna, kontyngenty, wywózki na roboty do Niemiec silnie oddziaływały na ludność. Aby zwielokrotnić strach okupant rozpowszechniał grupowe rozstrzeliwania w publicznych egzekucjach. Szczególną formą odpowiedzialności zbiorowej było mordowanie całych polskich rodzin udzielających pomocy Żydom (SZPYTMA 2004, s. 15-16).

Nieznane są szczegóły okoliczności, w których piątka Żydów z domu Szall oraz Genia i Gołda Goldman wraz z córką pojawili się w domu Ulmów. Trudno obiektywnie określić motywy, którymi kierował się J. Ulma, kiedy 
przygarnął ich pod swój dach. Wraz z Szallami garbował duże ilości skór, których sprzedaż dawała możliwość wykarmienia szesnastu osób. Pomimo korzystnego położenia, dom Józefa otoczony polami, nie nadawał się na „kryjówkę" (fot. 3). Budynek był mały, a cała ośmioosobowa rodzina Ulmów musiała pomieścić się w dwóch izbach. Niemal niemożliwe było stworzenie kryjówki dla tak wielu osób. Jednak znaczne ilości pożywienia, które raz po raz kupowała Wiktoria musiały wzbudzić podejrzenia uważnych obserwatorów. $Z$ pewnością zostały również zauważone duże ilości wyprawionych skór przez osoby, które przychodziły robić zdjęcia. Zarówno te, jak i inne okoliczności demaskować mogły tajemnicę, co wkrótce miało doprowadzić do tragedii.

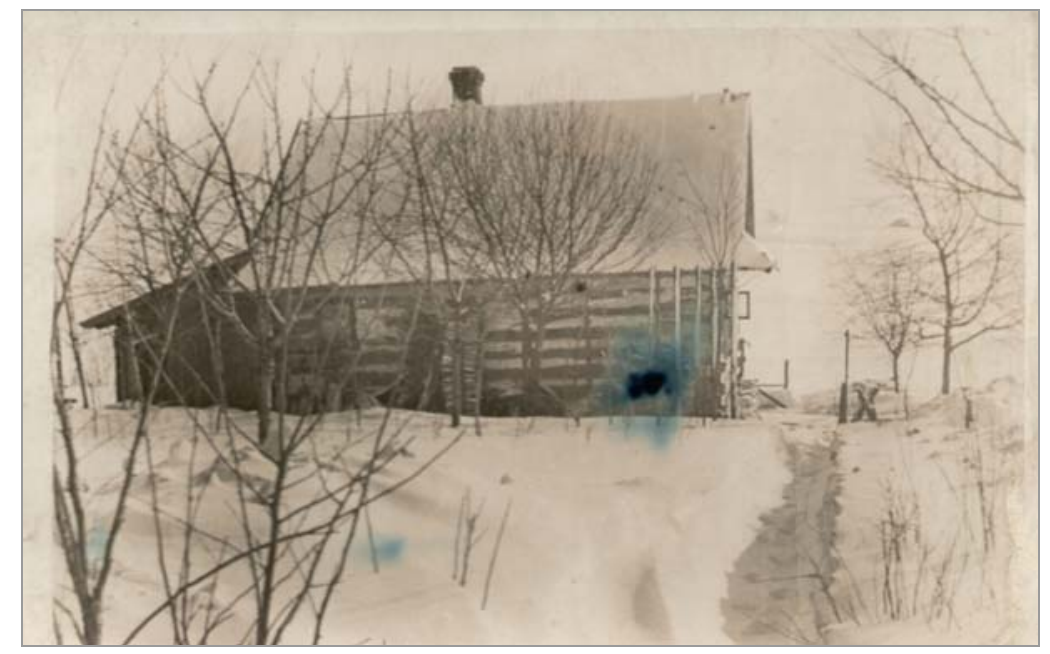

Fot. 3. Dom rodziny Ulmów (ok. 1938 r.) (ze zbiorów Jerzego Ulmy)

Wydarzenia, które rozegrały się 24 marca 1944 r. trwale zapisały się na kartach historii mieszkańców Markowej. Przygotowania do „wymierzenia sprawiedliwości” rozpoczęły się dzień wcześniej, kiedy łańcucka żandarmeria nakazała podstawienie pod posterunek czterech furmanek z okolicznych miejscowości. Wśród woźniców był młody, osiemnastoletni Edward Nawojski z Kraczkowej. Na miejsce kaźni wyjechało co najmniej ośmiu funkcjonariuszy; czterech żandarmów oraz czterech policjantów. Grupie przewodził szef posterunku w Łańcucie - porucznik Eilert Dieken, któremu towarzyszyli m.in. Joseph Kokott, Michał Dziewulski, Erich Wilde. Tuż przed 
nastaniem świtu Niemcy wraz z "granatową" obstawą udali się pod dom. Do śpiących jeszcze domowników brutalnie wdarli się i rozstrzelali podczas snu braci Szallów i Gołde Goldman. Resztę osób przebywających w domu wypędzili na zewnątrz. Dalsza część egzekucji odbywała się na oczach furmanów. E. Nawojski podaje, że zamordowano najpierw jednego z Szallów, a następnie Genię Goldman, wraz z jej małym dzieckiem, kolejnymi byli dwaj mężczyźni z rodziny Szallów. Zaraz potem na zewnątrz znaleźli się gospodarze, wraz z gromadką swoich małych dzieci. Wykonano wyrok na Józefie i Wiktorii, a po krótkiej naradzie E. Dieken zdecydował się wymordować również dzieci. E. Nawojski widział, jak dzieci zastrzelił J. Kokott. Zgromadzonym złowieszcze słowa wypowiadane przez niego po polsku zapadły w pamięci - krzyczał: „Patrzcie jak polskie świnie giną - które przechowują Zydów" (SZPYTMA 2004, s. 38).

W oparciu o akta sądowe i kontrolno-śledcze przeciwko J. Kokottowi można ustalić dość dokładny przebieg zbrodni². Wskazują one, że siedmiu mieszkańców Markowej, w tym sołtys Teofil Kielar, pojawili się z rozkazu Niemców dopiero po dokonaniu masowego mordu. Ich zadanie polegało na wykopaniu dołów i umieszczeniu w nich ofiar. Zaraz po dokonaniu eksterminacji okupanci przystąpili do grabieży majątku i przeszukania zwłok.

Bezpośrednio po akcji J. Dieken wraz z jednym z żandarmów udał się do położonego nieopodal posterunku policji w Markowej, gdzie udzielił nagany tamtejszemu komendantowi. Następnie wraz ze zrabowanym mieniem policjanci odjechali z Markowej. W przeciągu tygodnia grupa mężczyzn pod osłoną nocy rozkopała grób Ulmów i pochowała wszystkich w tym samym miejscu w trumnach. Jeden z nich opisuje: „Kładąc do trumny zwłoki Wiktorii stwierdziłem, że była ona w ciąży. Twierdzenie to opieram na tym, że z jej narządów rodnych było widać główkę i piersi dziecka"(SZPYTMA 2004, s. 41). Zwłoki zostały przeniesione na cmentarz dopiero 17 stycznia $1945 \mathrm{r}$. W roku 1995 przejawem pamięci oraz wdzięczności dla Józefa i Wiktorii ludzi ratujących Żydów w czasie niemieckiej okupacji, było przyznanie dyplomu i medalu „Sprawiedliwy wśród Narodów Świata”

\footnotetext{
2 Trudno określić, co stało się z M. Dziewulskim i E. Wildem. Wiadomo natomiast, że odszukany i osądzony został J. Kokott. W 1957 r. odnaleziono go w Czechosłowacji. W 1958 r. sąd w Rzeszowie uznał go za winnego dokonywania zabójstw i skazał na karę śmierci. Na wniosek Kokotta Rada Państwa PRL skorzystała z prawa łaski i zamieniła mu karę na dożywocie, a następnie 25 lat pozbawienia wolności. Zmarł w więzieniu w 1980 r.

${ }^{3}$ Obecnie odznaczenie to nadaje Instytut Pamięci Narodowej Yad Vashem w Jerozolimie osobom ratującym Żydów w czasie II wojny światowej. Na dyplomie i medalu widnieje napis: „Kto ratuje jedno życie, jakby świat cały ratował". Dodatkowo nazwisko wyróżnionej osoby jest wygrawerowane na tablicy oraz pod drzewkiem posadzonym w Parku Sprawiedliwych wśród Narodów Świata na Wzgórzu Pamięci w Jerozolimie. W roku 1993 w Markowej medal otrzymała również Helena Szylar razem z siostrą i nie-
} 
Wielu mieszkańców Markowej, podobnie jak rodzina Ulmów, przyjęło pod swój dach osoby pochodzenia żydowskiego dając im schronienie, posiłki, ryzykując własnym życiem i swoich najbliższych. Gospodarze nie ugięli się, mimo uczucia grozy i zatroskania o losy swoich rodzin, nadal pomagali Żydom ukrywając ich w swoich domach. Jak podają SZPYTMA, SZAREK (2004, s. 61-62), w Markowej końca niemieckiej okupacji doczekało co najmniej 17 osób pochodzenia żydowskiego.

\section{Materiał i metody}

Badania przeprowadzono w latach 2005-2011 we wsi Markowa oraz w sąsiednich miejscowościach - Łańcucie i Leżajsku. Są one kontynuacją wcześniej podjętych badań o szerszej problematyce dotyczącej zrównoważonego rozwoju miejscowości pielgrzymkowych (por. PÓŁTORAK 2009, s. 145-156). Rozpoznanie budzącego zainteresowanie zjawiska, jakim jest rozwój turystyki pielgrzymkowej we wsi Markowa, jest efektem pamięci i czci bohaterskich postaw ofiar II wojny światowej. Przedmiotem badań były osoby uczestniczące $w$ ruchu pielgrzymkowym, przyjazdach w celu poznania miejsca, historii tragicznie pomordowanych rodzin, wydarzeń upamiętniających koleje losu oraz inne osoby kierujące się własnymi motywami. Hipotezę stanowi przypuszczenie, że wydarzenia historyczne związane $\mathrm{z}$ ratowaniem ludności żydowskiej oraz ofiara poniesiona przez ratujących przyczyniają się do rozwoju ruchu turystycznego na obszarach, które nie mają szczególnych atrakcji turystycznych, co w konsekwencji determinuje pewien rozwój społeczno-kulturowo-gospodarczy małych miejscowości.

Narzędziami badawczymi były metody monografii i indywidualnych przypadków, które posłużyły poznaniu biografii rodziny Ulmów i wydarzeń z okresu poprzedzającego wybuch II wojny światowej oraz jej przebieg. W tym celu zgromadzono wystarczający materiał dokumentujący losy rodziny i wydarzeń w postaci archiwaliów stanowiących własność najbliższej rodziny. Technikami badawczymi zastosowanymi do gromadzenia danych i rejestru liczby odwiedzających były: obserwacja okolicznościowych uroczystości i imprez, wywiady z pracownikami Centrum Kultury Gminy Markowa i analiza liczby wpisów do księgi pamiątkowej, a także rozmowy z przedstawicielami społeczności lokalnej i pozyskiwanie informacji na te-

żyjącymi już rodzicami, oraz Janina Bar i jej nieżyjący rodzice Józef i Julia. Ogółem do 1 stycznia 2007 r. na 21758 przyznanych medali Polacy otrzymali najwięcej spośród wszystkich narodowości, bo aż 6004 . 
mat liczby zaproszonych gości. Prowadzony rejestr został uzupełniony również o wywiady z osobami odwiedzającymi i przybywającymi na uroczystości oraz rozmowy z najbliższą rodziną i mieszkańcami. Uszczegółowieniem prowadzonych badań była analiza rozlicznych dokumentów i fotografii, z których można było szacować liczbę osób przybywających do miejscowości. Wiele tych źródeł informacji, $\mathrm{z}$ uwagi na wymogi techniczne, jakie nałożono na autorów tekstów, nie zostało przedstawionych w niniejszym artykule.

\section{Znaczenie ofiary rodziny Ulmów dla rozwoju turystyki}

Analiza uzyskanych wyników wykazuje, że główny udział w ruchu turystycznym w Markowej przypada ludności pochodzenia żydowskiego. Pielgrzymujący Żydzi stanowią bowiem znaczny odsetek wśród wszystkich odwiedzających. Z danych uzyskanych od osób pracujących w Centrum Kultury Gminy Markowa (za lata 2009-2011) oraz własnych wywiadów z przedstawicielami miejscowych władz i mieszkańcami wsi, analizy wpisów do Księgi Pamiątkowej oraz czynionych obserwacji (w latach 2005-2011) wynika, że od 2005 r. liczba przyjeżdżających Żydów systematycznie wzrastała. W roku 2005 Markowę odwiedziło blisko 2000 osób pochodzenia żydowskiego, a w kolejnych latach ich liczba systematycznie zwiększała się, tak by w 2011 r. wielkość móc oszacowań na ok. 6700 osób (rys. 1).

Prezentowane dane mają charakter jedynie szacunkowy, gdyż nikt do tej pory dokładnych pomiarów nie prowadził, a sumowanie odbywało się m.in. na podstawie analizy rozlicznych dokumentów, fotografii, wywiadów i własnego rejestru. Od roku 2009 Centrum Kultury Gminy Markowa rozpoczęło prowadzenie takiego rejestru, ale - jak twierdzą pracownicy tej instytucji - nie jest on kompletny. Prezentowane wartości liczbowe w celu zilustrowania jedynie ogólnego rozmiaru ruchu turystycznego, zostały zaokrąglone do stu.

Pomnik rodziny Ulmów odwiedzają nie tylko Żydzi w celach pątniczych, ale również inne osoby zaciekawione losem rodziny oraz ich postawą. Wśród nich są mieszkańcy Markowej, dzieci, młodzież, mieszkańcy okolicznych wsi i miast, jak również przedstawiciele władz państwowych, regionalnych, lokalnych i różnych organizacji oraz duchowieństwa (rys. 2). Zdarzają się również osoby przyjeżdżające $\mathrm{z}$ odległych miejscowości, ale ich wizyta w Markowej była jedynie postojem na trasie podróży. Jak ustalono, w 2005 r. 
Liczba (tys.)

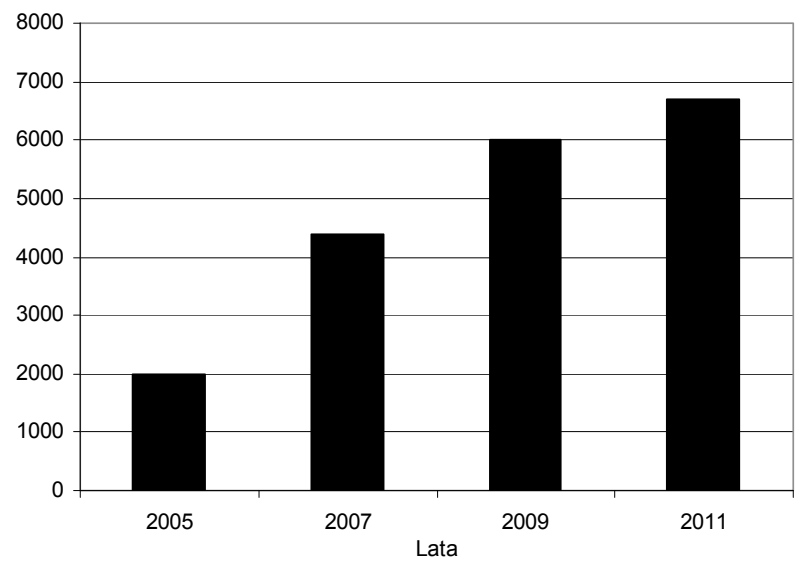

Rys. 1. Liczba Żydów odwiedzających Markową w latach 2005-2011

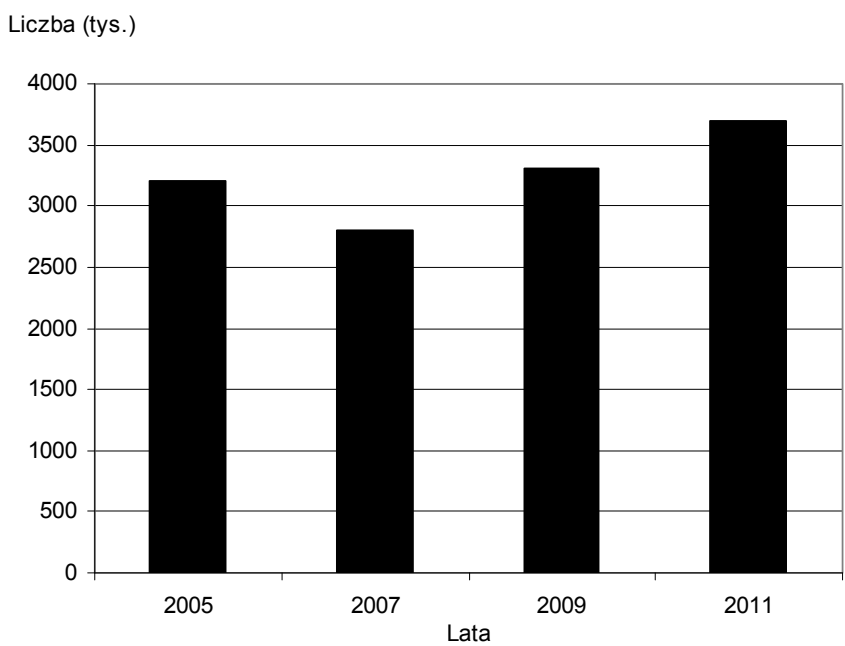

Rys. 2. Liczba osób odwiedzających Markową w latach 2005-2011

liczba odwiedzających wyniosła ok. 3200, natomiast w roku 2007 była niższa. Powodem wyższej frekwencji w 2005 r. było wybudowanie rok wcześniej pomnika ku czci Ulmów i pomordowanych Żydów, a wydarzenie to zostało szeroko rozpowszechnione przez rozliczne media. W kolejnych latach można zaobserwować systematyczny wzrost liczby osób przyjeżdżających do Markowej. Najczęściej uzasadniali oni powód swojej wizyty motywami: poz- 
nawczymi, pątniczymi, zaspokojenia ciekawości, dopełnienia wiedzy, gromadzenia własnej dokumentacji.

Rysunek 3 ilustruje proporcję między liczbami osób pochodzenia żydowskiego i polskiego, którzy odwiedzili do tej pory Markowę. Z analizy danych liczbowych wynika, że na przestrzeni lat większość wśród odwiedzających stanowią pielgrzymujący Żydzi. Jednak zauważa się systematyczną tendencję wzrostową wśród liczby turystów zarówno pochodzenia żydowskiego, jak również polskiego, co przekonuje o rozwoju turystyki pielgrzymkowej i poznawczej w Markowej.

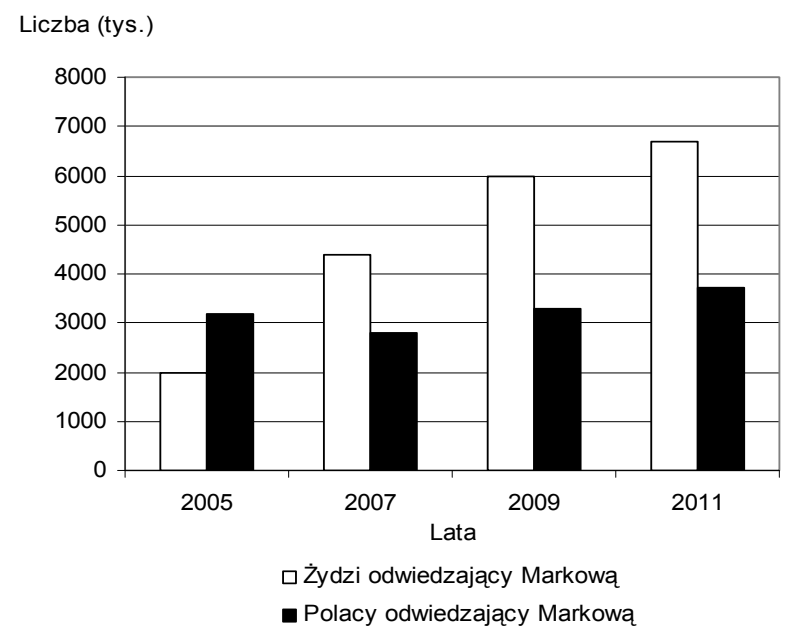

Rys. 3. Zestawienie liczbowe odwiedzających Markową w latach 2005-2011

Jak wynika z prezentowanych danych $\mathrm{w}$ ostatnich latach wydarzenia związane z rodziną Ulmów silnie wpływają na wizerunek wsi. Od momentu odsłonięcia pomnika, tj. od 24 marca 2004 r. obchodzone są uroczystości ku czci rodziny Józefa i Wiktorii. Wówczas do Markowej zjeżdżają goście z różnych organizacji, przede wszystkim przedstawiciele polskiego Instytutu Pamięci Narodowej, Sejmu, władz Podkarpacia, przedstawiciele duszpasterstwa, jak również ze świata. Jednym z nich był Abraham Segal - uratowany przez mieszkańców Markowej (SZPYTMA, SZAREK 2007, s. 69-72). Do tej pory hołd Ulmom złożyli m.in. Jarosław Kaczyński, wicepremier Waldemar Pawlak, wicemarszałek Sejmu Marek Kuchciński i inni.

23 marca 2006 r. w dniu obchodów 62. rocznicy tragedii miejscowa szkoła przyjęła imię Sług Bożych Rodziny Ulmów. Przy okazji wizyt specjalnie dla grupy młodych żydowskich pielgrzymów w Centrum Kultury Gmi- 
ny Markowa organizowane są spotkania z młodzieżą markowską w celu przybliżenia losów rodziny Ulmów, poznania wzajemnej historii, zaznajomienia się z odrębną kulturą i religią.

W roku 2003 rozpoczął się proces beatyfikacyjny rodziny Ulmów. Dużą radością dla mieszkańców Markowej jest fakt, że Ulmowie są w grupie 122 kandydatów na ołtarze, męczenników II wojny światowej. Proces beatyfikacyjny rodziny jest częścią większego przedsięwzięcia i postępowania, dotyczącego ponad 100 męczenników, ofiar czasów II wojny światowej. Diecezja pelplińska koordynowała prace nad dokumentacją procesu i po zakończeniu całej procedury na terenie Polski przekazała stosowny akt do Watykanu (Polacy ratujacy... 2011, s. 10-11).

Pamięć o rodzinie Ulmów jest wciąż żywa, a ich historia rozgłaszana nie tylko w Polsce, ale i na całym świecie. Informacje o Ulmach ukazywały się w obcojęzycznej prasie, m.in. włoskiej i amerykańskiej. Powstała również wystawa z inicjatywy Instytutu Pamięci Narodowej pt. „Samarytanie z Markowej Ulmowie - Polacy zamordowani przez Niemców za pomoc Żydom", która pokazywana była w wielu miastach w Polsce. Ostatnio ekspozycję mogli obejrzeć mieszkańcy Monachium. Powstał również film dokumentalny w reżyserii Rafała Wieczyńskiego pt. „Świat Józefa”. Premierowa emisja filmu miała miejsce 5 listopada $2010 \mathrm{r}$. w pierwszym programie TVP.

Wzrastająca liczba zainteresowanych tematem ofiary rodziny Ulmów jest jednym z powodów, dla których postanowiono utworzyć w Markowej Muzeum Polaków Ratujących Żydów na Podkarpaciu im. Rodziny Ulmów (fot. 4).

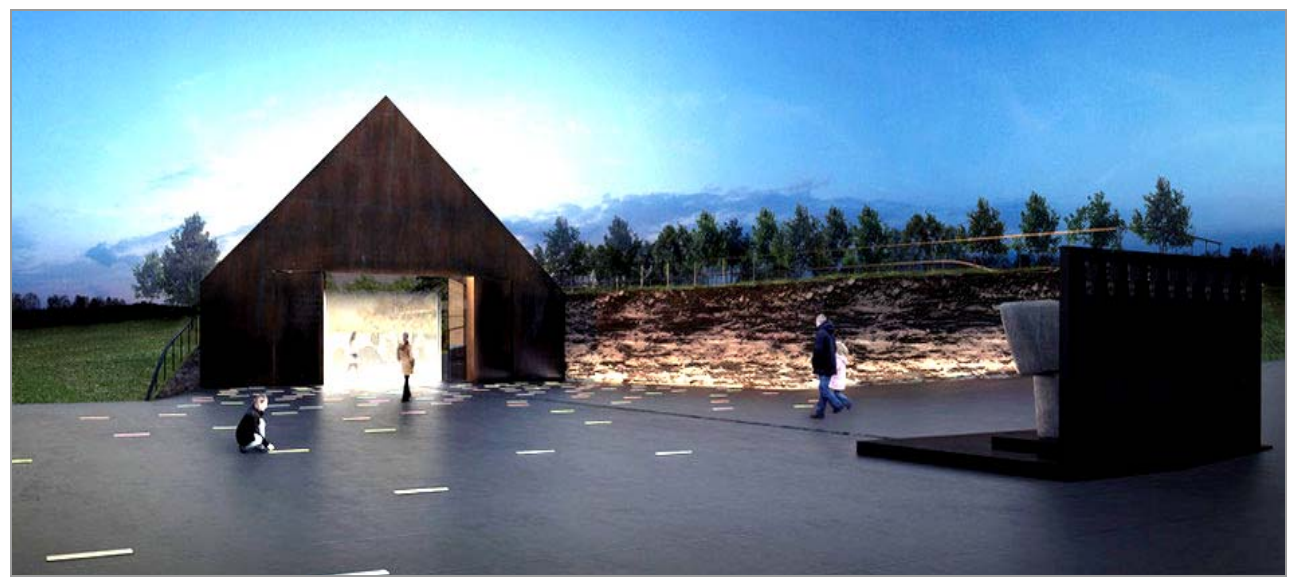

Fot. 4. Projekt Muzeum Polaków Ratujących Żydów na Podkarpaciu im. Rodziny Ulmów Źródło: www.architektura.info z dnia 25. 05. 2011 r. (wizualizacja i widok od placu - z narożnika południowo-wschodniego) 
Muzeum ma stać się jednym z najnowocześniejszych w Polsce. Projekt budynku został wybrany w drodze konkursu. Zwyciężyła koncepcja architektoniczna pracowni Nizio Design International, w której zaprojektowano m.in. wnętrza Muzeum Powstania Warszawskiego w Warszawie oraz Muzeum Martyrologii Wsi w Michniowie. Autorzy projektu przewidują pokazy multimedialne, nagrane na wideo wypowiedzi świadków historii. Najważniejszym eksponatem ma stać się dokładnie odtworzony dom rodziny Ulmów, ze skrytkami na strychu, gdzie ukrywali się Żydzi. Zwiedzającym towarzyszyć ma komentarz wyjaśniający historię i sytuację Polski okupowanej przez Niemców. Prace nad muzeum mają trwać do 2014 r.

\section{Podsumowanie i wnioski}

Niniejsze opracowanie przedstawia związek pomiędzy tragicznymi wydarzeniami z II wojny światowej, jakim była eksterminacja Żydów i pomoc im udzielana przez mieszkańców wsi Markowa, a powstaniem ogólnego zainteresowania tą kwestią $\mathrm{w}$ obecnych czasach. Owe zainteresowanie przyczynia się do wzrostu liczby odwiedzających wieś, zarówno obcokrajowców, jak i Polaków, co w konsekwencji generować może w przyszłości pewien rozwój społeczno-ekonomiczny miejscowości.

Siłą sprawczą rozwoju turystyki w Markowej są pielgrzymki Żydów. Markowa stała się bowiem kolejną ważną miejscowością na ich szlaku pielgrzymkowym po Leżajsku i Łańcucie. Zarówno dorośli, jak i młodzież, zbierają się licznie wokół pomnika, oddając hołd rodzinie Ulmów. Obecnie turyści przybywający do Markowej indywidualnie bądź w grupach zorganizowanych gromadzą się przed pomnikiem rodziny Ulmów, odwiedzają również grób Ulmów na miejscowym cmentarzu oraz Skansen-Muzeum Wsi Markowa. Motywami, jakimi kierują się najczęściej są: poznanie i upamiętnienie miejsca, uczestnictwo w obchodach rocznicowych, zaspokojenie ciekawości, dopełnienie wiedzy, gromadzenie materiałów na własne potrzeby $\mathrm{i}$ inne.

W ostatnich latach wydarzenia związane z rodziną Ulmów silnie wpłynęły na wizerunek wsi. Podejmowane działania, tj. rozpoczęcie procesu beatyfikacyjnego, budowa pomnika, organizowanie wystaw i spotkań, powstanie projektu wybudowania Muzeum Polaków Ratujących Żydów na Podkarpaciu im. Rodziny Ulmów istotnie zmieniają liczbę osób odwiedzających wieś. Fakt ten przyczynił się do rozwoju ruchu turystycznego o charakterze 
pielgrzymkowym i poznawczym. W konsekwencji stan taki może spowodować dynamiczny rozwój wsi zarówno pod względem społecznym, ekonomicznym, jak i turystycznym. Jednak z przeprowadzonych badań wynika, że aktualnie Markowa nie jest odpowiednio przygotowana do przyjmowania tak dużej liczby turystów. W przyszłości niewątpliwym generatorem rozwoju wsi pod względem turystycznym stanie się Muzeum Polaków Ratujących Żydów na Podkarpaciu im. Rodziny Ulmów. Autorzy przewidują że nowoczesna inwestycja przyciagnie turystów nie tylko z Polski, ale i ze świata. Wzrost liczby odwiedzających przyczyni się do odkrycia potencjału wsi jako miejscowości turystycznej. Nastąpi rozwój podstawowej infrastruktury turystycznej, tj. bazy noclegowej i gastronomicznej oraz uzupełniającej świadczącej usługi turystom i mieszkańcom.

\section{BIBLIOGRAFIA}

DoBOsz S., 1993, W walce z okupantem hitlerowskim, [w:] J. Półćwiartek (red.), Z dziejów wsi Markowa, Wyd. Towarzystwo Przyjaciół Markowej, Rzeszów.

Polacy ratujacy Żydów zostana upamiętnieni, 2011, „Tygodnik Rodzin Katolickich «Źródło»”, 12 (1003).

POTOCKI A., 2004, Żydzi w Podkarpackiem, Wyd. Libra, Rzeszów.

PÓŁTORAK W., 2006, Rekreacja fizyczna i wychowanie zdrowotne w Wiejskim Uniwersytecie Ludowym im. W. Orkana w Gaci (1906-1975), [w:] Studia i szkice z dziejów turystyki na Podkarpaciu, S. Zaborniak (red.), Prace Dydaktyczne PWSZ w Krośnie, 23.

PÓŁTORAK W., 2009, Zrównoważony rozwój miejscowości pielgrzymkowych na przykładzie Leżajska, [w:] Dziedzictwo kulturowe szansa rozwoju turystyki w regionie, K. Obodyński, M. Duricek, A. Nizoł (red.), Akademia Europejska na rzecz Euroregionu Karpackiego, Polskie Towarzystwo Naukowe Kultury Fizycznej, Rzeszów.

PTASZYCKA-JACKOWSKA D., 2007, Turystyka religijna (turystyka pielgrzymkowa), [w:] W. Kurek (red.), Turystyka, Wydawnictwo Naukowe PWN, Warszawa.

SZPYTMA M., 2004, Żydzi i ofiara Rodziny Ulmów z Markowej podczas okupacji niemieckiej, [w:] S. Mendelowski, M. Szpytman (red.), W gminie Markowa, t. II, Wyd. PUW „Roksana”, Markowa.

SZPYTMA M., SZAREK J., 2004, Ofiara sprawiedliwych, Rodzina Ulmów - oddali życie za ratowanie Żydów, Dom Wydawniczy „Rafael”, Kraków.

SZPYTMA M. SZAREK J., 2007, Sprawiedliwi wśród narodów świata, Dom Wydawniczy „Rafael”, Kraków.

WAWSZCZAK Z., 1993, Józef Ulma (1900-1944), [w:] J. Półćwiartek (red.), Z dziejów wsi Markowa Wyd. Towarzystwo Przyjaciół Markowej, Rzeszów.

www.architektura.info (z dnia 25.05.2011 r.). 